\title{
The cognitive basis of diglossia in Arabic: Evidence from a repetition priming study within and between languages
}

This article was published in the following Dove Press journal:

Psychology Research and Behavior Management

I September 2009

Number of times this article has been viewed

\section{Raphiq Ibrahim}

Edmond J. Safra Brain Research Center for the Study of Learning Disabilities, Department of Learning Disabilities, University of Haifa, Haifa, Israel
Correspondence: Raphiq Ibrahim Edmond J. Safra Brain Research Center for the Study of Learning Disabilities, Department of Learning Disabilites, Haifa University, Haifa 31905, Israel

Fax +97204824 091।

Email raphiq@psy.haifa.ac.il

\begin{abstract}
This study examined diglossia and its cognitive basis in Arabic. Repetition priming effects were compared within spoken Arabic (SA), as well as with the effects found when the primes were in either literary Arabic (LA) or Hebrew. In experiment 1, using lexical decisions for auditory presented words, a significant priming effect was found at lag 0 when the primes were in LA and in Hebrew. Furthermore, large repetition priming effects were found at relatively long lags (lag 8-12) within SA. This effect was absent when the repetition involved translation equivalents using either Hebrew or LA. The results showing that lexical decisions for words in SA were not influenced by previous presentations of translation equivalents in LA, in addition to the findings from a former study on semantic priming effects, suggest that the status of LA is similar to that of Hebrew and is consistent with the typical organization of L2 in a separate lexicon. Thus, learning LA appears to be, in some respects, more like learning a second language than like learning the formal register of one's native language.
\end{abstract}

Keywords: spoken Arabic, literary Arabic, bilingualism, repetition priming, translation equivalents, lexical organization

\section{Introduction}

Research on bilingualism over the past three decades has focused on the nature of the representation of words in the bilingual's mental lexicon and the effect of bilingualism on cognitive and paralinguistic development (for a review, see Kroll and de Groot). ${ }^{1}$ Of particular interest are questions addressing the relationship between semantically related words and translation equivalents across languages and the manner in which words in each language are connected to their meanings. ${ }^{2}$

In the case of the Arabic language, a diglossic situation arises from the gap between the language of orality (ammia), or everyday spoken Arabic dialect (SA), and the language of literacy (fuṣha), more commonly referred to as literary Arabic (LA) or modern standard Arabic (MSA). This study was designed to examine whether the psychological reality of diglossia, in which the two languages may be considered as two forms of one, affects the lexical organization in the cognitive-linguistic system of native speakers of SA. Specifically, this study attempts to address the core question in bilingualism: What is the linguistic distance required between two languages in order to be represented in a bilingual manner?

In the last decade, researchers in Arabic investigated if this gap could be a major cause of low learning achievement in schools and low adult literacy levels everywhere in the Arab region. ${ }^{3-5}$ Abu-Rabia ${ }^{4}$ investigated the contention that reading difficulties in Arabic in elementary school result from the diglossic situation whereby fuṣha, the 
language of books and school instruction, is in opposition to the spoken dialect of the home. Saiegh-Haddad ${ }^{5}$ examined the role of oral language in the acquisition of basic fusha reading processes, exploring the interface between exposure to fuṣha and the development of top-level reading comprehension skills. Understanding this relationship is vital in formulating a theory of initial reading acquisition in diglossic or bidialectal settings. Moreover, Saiegh-Haddad moved beyond just establishing a possible causal link between exposure to fuṣha and achieving top-level reading comprehension skills. Namely, he addressed the issue of whether diglossic variables or linguistic distance parameters interfere with the acquisition of basic reading processes in fuṣha. The study showed that diglossia and the phonological distance between the two varieties of Arabic were indeed related to the native decoding ability of the young Arab children.

Maamouri ${ }^{3}$ claimed that fusha, which is at the same time 'formal Arabic' is difficult to learn and use because it is nobody's native language. He argued that fuṣha and dialectal Arabic code-switching constitute a major cause of serious pedagogical problems that can lead to inadequate language competence, low linguistic self-confidence, and consequent social problems. Psycholinguistics studies have focused on the cognitive basis of these difficulties. Ibrahim and colleagues attempted to identify the psycholinguistic basis for processing Arabic language. Furthermore, they examined the relationship between the Arabic orthographic system and cognitive processes that might be involved during word processing. ${ }^{6-8}$ Specifically, Eviatar and Ibrahim ${ }^{6}$ focused on the effect of early exposure to the two forms of Arabic on cognitive and metalinguistic awareness. Metalinguistic awareness refers to the ability to think about the linguistic nature of the message and to be aware of certain properties of language, such as its arbitrariness and phonological structure. $^{9}$ Given that bilingual children reveal heightened metalinguistic abilities as a result of acquiring two rather than one linguistic systems, the same theory was applied to newly literate Arab children in order to determine whether this effect is evoked before they have been exposed to any other language.

Operationally, the two Arabic linguistic systems (spoken and MSA) were examined to ascertain whether they promote the development of cognitive strategies that result in heightened metalinguistic abilities in young children. Three samples of children were tested: Hebrew monolinguals; Russian-Hebrew bilinguals who came from Russian-speaking homes of immigrants and attended school in Hebrew; and Arabic speakers whose first language was spoken Arabic but who also had exposure to LA via children's books, television, and formal instruction in kindergarten and first grade. The results of the Arabic speakers revealed similar performance levels in metalinguistic tests as compared to Russian-Hebrew bilinguals and higher performance as compared to monolinguals. The researchers concluded that exposure to MSA in early childhood affects their metalinguistic skills in the same manner as that reported for children who are exposed to two different languages.

Another related issue is whether the similarity among languages influences bilingual linguistic performance. One longitudinal study of literacy acquisition in Moroccan children investigated whether preschool experience with a spoken Moroccan Arabic dialect facilitated literacy acquisition differently from preschool experience with Berber, a member of the Hamitic family of languages that has no semantic or syntactic similarity to Arabic. ${ }^{10}$ This study compared the performance of monolingual and bilingual Arabic- and Berber-speaking children in learning to read MSA and French. The results showed an advantage for the Arabic-speaking children over the Berber-speaking children in learning to read MSA, whereas the preschool experience of the two language groups had little effect on learning to read French. The researchers concluded that the superiority of the Arabic-speaking children in the early stages of MSA literacy acquisition was due primarily to the substantial similarity and transfer from spoken Moroccan Arabic to MSA, but not to French.

Although many authors have focused on the psycholinguistic reality that influences bilingual performance, only a few studies have directly addressed the question of lexico-semantic organization. ${ }^{7,11}$ In this context, Ibrahim and Aharon-Perez $\mathrm{z}^{7}$ compared the semantic priming effects within SA (L1) with the effects found across languages, with LA or Hebrew as the other language (L2). The results revealed that the cross-lingual semantic priming effects on SA targets were practically identical for LA and Hebrew and were significantly lower than the intra-lingual semantic priming in SA. For both language pairings, the semantic priming was larger when the primes were presented in SA (and the targets in either Hebrew or LA) than when the primes were presented in one of the second languages and the targets in SA.

This pattern is in line with the revised model, based on the assumption that cross-lingual semantic priming is asymmetrical. ${ }^{12}$ It is also consistent with previous research on other languages. ${ }^{13,14}$ The observed asymmetry of priming efficiency is usually attributed to the fact that words in a second language have looser connections with 
their meanings than do words in the first language. One caveat about these findings is that although the authors focused on the psycholinguistic reality influencing bilingual performance, they did not directly address the question of lexical organization. This assumption is justified explicitly on the basis of prior research.

On the grounds of previous work, ${ }^{15}$ one would expect to find greater repetition priming in the condition of intra-lingual repetition (when a word in spoken Arabic is repeated) than in the condition of cross-lingual repetition of translation equivalents. Hence, long-lasting cross-language repetition effects between translation equivalents would, by necessity, indicate the existence of lexical links or reactivation of the same concept. A possible explanation for the significant crosslingual immediate repetition priming is that, like semantic priming, it is based on short-lasting activation in the semantic system. The absence of cross-lingual long-lasting effects shows that reactivation of the same concept is insufficient to induce long-lasting priming effects. Moreover, words in L1 and L2 do not entertain active lexical connections, meaning that the activation of a word in one language does not activate its translation equivalent in the other language.

Such an interpretation (at least in balanced bilinguals or those who master their second language well) is in line with the revised developmental model of bilingual organization suggested by Kroll and Stewart. ${ }^{12}$ According to this model, connections between translation equivalents at the lexical level are asymmetrical. Words in the second language have a much greater tendency to activate their translations in the first language than vice versa. ${ }^{16}$ The magnitude of this asymmetry, however, may change across individuals or within individuals across time, as determined by the bilingual's particular proficiency in the second language. ${ }^{17}$

\section{Linguistic background of Arabic-speaking adults in Israel}

Given the focus of this research on diglossia among native speakers of SA, it is necessary to understand the cultural setting in which the research was conducted. Native Arabicspeaking children in Israel, as in the rest of the Arab world, use a different local dialect of SA that has no written form. Some literacy specialists see LA as somewhat disconnected from the everyday reality of adult learners' needs. Both differ considerably on phonetic, phonologic, morphosyntactic, and semantic levels.

At the phonetic level, pronunciation can vary according to context. For example, the vowels ' $\varepsilon$ ' and ' $o$ ' in SA are pronounced in LA, depending on phonetic context, either as 'æ' or ' $i$ ' and 'au' or ' $u$ ', respectively. Whereas words in LA may not begin with two consecutive consonants (or with a consonant and a 'schwa'), many words in SA do. Different inflections are used in each language (such as the suffix which marks the plural in each language). Because SA uses fewer words than LA, the same phonological unit in SA may represent related meanings which are represented by different words in LA (eg, the word "chin" is also used for "beard" and "goat" for "stupid").

At the morphological and the syntactic level, the grammatical functions are represented by the short vowels, indicative of mood and case endings among other linguistic functions. Thus, vocalic representation carries the weight of the whole grammatical system and is therefore extremely important in setting up functions leading to correct reading and acceptable text understanding. However, these short vowels are rarely present in everyday writing, and they do not, as a rule, appear in most printed materials in the Arab region.

At the semantic level, there is a semantic gap between SA and MSA. For example, the word 'balcony' in English is ' in SA, as opposed to 'برندة' in LA. Therefore, a lexicosemantic representation of a spoken word might differ from its representation in the standard version even though it is related to the same concept. At the phonological level, there is a gap between SA and MSA. For example, the word 'dog' in English is pronounced as 'kalb' in the classical Arabic and 'kalib' in the spoken one (adding the phoneme 'I'). Likewise, the word 'officer' is pronounced as 'dabet' in the classical Arabic and 'zabet' in the spoken one (substituting the phoneme 'd' with ' $z$ '). Therefore, a specific phonological representation of a spoken word might differ from its phonological representation in the standard version even though it is phonetically related to it. ${ }^{18}$

Israeli Arab adults learn Hebrew as a second language and English as an additional language. Hebrew studies are started in the second grade on the basis of LA. Because Hebrew is the official language of the country, Israeli Arab students master Hebrew as well as LA. Furthermore, in high school, second language (Hebrew) instruction usually exceeds Arabic language instruction, particularly in science subjects, such as math, biology, and technology, which are taught in Hebrew as dictated by the official Israeli curriculum in all public schools.

In the context of this unique linguistic situation of Israeli Arab students, the aim of this study was to examine if the diglossic situation can be treated as a bilingual situation. The basic methodological considerations followed when 
choosing the sample population were finding subjects whose first spoken language and first learned language was Arabic and ensuring that the uniform dialect of SA was suited to the subject population. With this in mind, the study was conducted among students from the Druze minority group who were attending geographically close high schools (Western Galilee area) and spoke the same dialect. All participants started to learn LA and Hebrew at school in the second grade and were equally proficient in the two languages.

The lifestyle, language, and social norms of the Druze are similar to those of Arab society. Despite the strong native-language cohesion characterizing both groups, they differ in their identification with the majority (Jewish) group. Based on a historical alliance with the Jewish people, the Israeli Druze have close ties with Israeli society, on the one hand, and strong identification with the Arab culture and language, on the other hand. ${ }^{19,20}$ Students in the Druze Arab school system begin to learn to read MSA in first grade, to speak Hebrew in second grade, and to read and write in Hebrew and in English in third grade. At the high school level, most students are as proficient in Hebrew as they are in MSA. Ibrahim and Aharon-Perez ${ }^{7}$ examined the status of MSA and Hebrew in high school students. The logic is the following: if MSA constitutes a second language for the Arabic speaker, then the results obtained regarding the lexical status of MSA words and their connections to meaning should be similar to patterns found for Hebrew. On the other hand, if the daily interactive use of SA and MSA, along with the sociolinguistic reality in which the two languages may be considered two forms of one language, have led to the combination of both forms of Arabic in a single lexicon, the results of linguistic manipulations between the two forms of Arabic should resemble those known to exist when the same linguistic manipulations are performed within a language. The relations between the two forms of Arabic were compared to the relations existing between Hebrew and SA. Ibrahim compared semantic priming effects within SA with the effects found across languages, with MSA or Hebrew being the other languages. The results in all of the studies were consistent and straightforward: When both the primes and the targets were presented in SA, the semantic priming effect was significantly greater than when the prime and target words were from MSA or Hebrew. Most importantly, the cross-language priming effects on response times were virtually the same, regardless of whether the second language was Hebrew or MSA. As with the young children, these findings suggest that the representation of MSA is that of a second language, similar to Hebrew, and that SA and MSA have the status of two separate languages in the cognitive systems of Arabic speaking adolescents.

These findings align nicely with previously reported asymmetry in cross-lingual semantic priming). ${ }^{13,14,21}$ The interpretation of the difference between the patterns of priming within and across languages is that words in a second language have looser connections with their meanings than do words in the first language. Therefore the semantic priming pattern described above suggests that, at least in regard to their connections with the semantic network, MSA, as well as Hebrew, constitute second languages for the bilingual native speaker of SA.

The present research used lexical relationships, repetition priming, and a lexical decision task in two experiments in order to explore the connections between translation equivalents in LA, SA, and Hebrew. Since the use of written language is unnatural in the context of spoken Arabic, the experiments presented the words in the auditory modality. In Experiment 1, translation equivalents in SA and LA and SA and Hebrew were compared for intra-lingual and cross-lingual repetition effects at lag 0 when no stimuli were intervening. In Experiment 2, intra-lingual and cross-lingual repetition effects at lags ranging between 8 and 12 items were compared. Experiment 1 initially established how cross-linguistic priming works for a semantic locus at lag 0, whereas Experiment 2 elaborated on the findings by examining how distinct the differences are between SA, Hebrew, and LA, and whether the priming effects still remain after a longer period of time. If SA and LA words are organized in the same lexicon, one that is different from that in which Hebrew words are stored, then we may see long-lag repetition priming from LA to SA, but not from Hebrew to SA. Therefore, assuming that SA is phonologically closer to LA than is Hebrew, words in LA would be expected to activate their translations in SA to a greater extent than would words in Hebrew.

\section{Experiment I}

Using lexical decision time and accuracy as dependent variables, many studies showed a robust identical-repetitionpriming effect, which, unlike semantic priming, lasted across many unrelated words intervening between the prime and the target (repetition lag). ${ }^{22}$ The longevity of the repetition effect relative to semantic priming reflects a difference in the priming mechanisms that account for these two effects. Unlike the semantic priming paradigm in which the prime and the target are different words and, therefore, priming effects may occur only at the semantic level, in the identical repetitionpriming paradigm the prime and the target are the same word. 
Consequently, in addition to reactivating the same meaning, word repetition reactivates the word's lexical/phonological structure, and its form (orthographic or phonetic). Several studies showed that form (orthographic) repetition is insufficient to account for all long-lasting priming effects. ${ }^{23}$ Therefore, the reliable long lasting repetition effects found in monolingual studies probably result from a combination of lexical and mnemonic sources of activation. ${ }^{24}$ In particular, the involvement of lexical/morphological (rather than pure phonological or semantic) sources in the long-lag repetition effect is suggested by the absence of such effects for nonwords, ${ }^{25}$ and by the significant long lasting effects of partial (morphologic) repetition even when primes and targets share no obvious semantic features. ${ }^{26}$

When the prime and the target are the same word, this could lead to a rapid performance of lexical decisions for targets in SA, whereas this facilitation would not occur when the primes are translation-equivalents in LA and Hebrew. Specifically, the translation equivalents would not prime SA target words after a long lag, regardless of whether they are in LA or Hebrew. This pattern in the cross-language condition might indicate that translation equivalents are not linked at the lexical level, but rather may be indirectly connected via the semantic system. Experiment 1 was designed to test this possibility using shorter lags (lag 0) between primes and targets.

\section{Method}

\section{Participants}

The participants were 30 native Arabic speakers (SA), who were students in the 11 th and 12 th grades from the same population. All participants were right-handed and neurologically normal and without any known learning disabilities.

\section{Stimuli and design}

The stimuli used in the present study were 384 phonologically legal structures used in the lag 0 repetition condition.
The stimuli were equally divided between 192 words and 192 pseudowords. In each stimulus group, 96 were primes and 96 were targets. The rated word frequency of all targets was average $(3.95,3.89$, and 4.06 on a scale ranging from 1 [lowest frequency] to 7 [highest frequency]) for the noncognate words. Within each of the priming language conditions, half of the targets were unrelated to their primes, and the other half were the translation equivalents of the primes. Across subjects, the stimuli were rotated so that each target-prime pair in each translation condition appeared equally at lag 0 . The pseudowords were constructed to mimic the real words.

Since the lexical links between languages are supposedly asymmetrical (stronger from L2 to L1 than vice versa), the cross-lingual primes in this experiment were in L2 (ie, the first appearance of repeated targets was in one of the three languages - SA, LA, or Hebrew - with 16 in each language), and the second appearance was always in SA (see examples in Table 1). In the absence of reliable word frequency norms in SA, LA, or Hebrew, this parameter was determined empirically, as follows: 30 judges from the same student population who did not participate in the experiment itself were presented orally with a list of the 96 predesignated SA targets and were asked to rate the frequency of the SA targets using a scale ranging from 1 (least frequent) to 7 (most frequent). The mean rated frequency was 3.92, with a range of 2.6-5.5. The frequencies in the appendix relate to the words in SA, as the SA by definition has no written form and the frequencies of words are similar to those of the concepts. In view of this fact, it was assumed that the frequencies of the concepts' translation to LA and Hebrew words in the auditory modality are similar.

The pseudowords used in this study were derived from words in SA, LA, and Hebrew by changing one or two phonemes and were phonologically legal. The phonotactics of pseudoword pronunciation are in the same vein. The words in SA and Hebrew were recorded by a male native Arabic speaker from the same population as subjects who

Table I Spoken Arabic (SA) targets and literary Arabic and Hebrew noncognate primes (with English transliterations) and their English translations

\begin{tabular}{|c|c|c|c|c|c|}
\hline $\begin{array}{l}\text { Primes: } \\
\text { Literary } \\
\text { Arabic }\end{array}$ & $\begin{array}{l}\text { Targets: } \\
\text { Spoken } \\
\text { Arabic }\end{array}$ & English & $\begin{array}{l}\text { Primes: } \\
\text { Literary } \\
\text { Arabic }\end{array}$ & $\begin{array}{l}\text { Targets: } \\
\text { Hebrew }\end{array}$ & English \\
\hline غدا & بكرة & Tomorrow & انبوب & צינור & Pipe \\
\hline GADAN & BOKRA & & INBOOB & TSENOR & \\
\hline جوارب & آلسات & Socks & مروحة & מאוורר & Fan \\
\hline JAWAREB & KALSAT & & MIRWAHA & MIAVRER & \\
\hline
\end{tabular}


spoke the local dialect. Following computer processing, designed to equalize the volume and length of the words as much as possible (700 ms duration time, on average), a computer was used to orally present the stimuli to the participants through earphones.

In order to achieve a full rotation in which each target was paired with primes from all three languages and in both primed and unprimed repetition conditions, six stimuli lists were composed. Each list was presented to 10 other participants. Results were analyzed using ANOVA, in which the priming language effect and the repetition effect were examined within subjects and within targets.

\section{Procedure}

The task was an auditory lexical decision. Participants were presented with a mixed list of SA, LA, and Hebrew spoken words and pseudowords and were instructed to decide whether each stimulus was a word or not in the language to which it belonged. Pairs of translation equivalents were inserted in this list. In all cases, the first word of the pair (the prime) was presented in either SA, LA, or Hebrew, and the second word (the target) was presented in SA. For each language, all the targets followed the primes immediately (lag 0 ) and all the translation equivalents were noncognates.

\section{Results}

Outlying reaction times (RTs), more than two standard deviations from the mean of each participant in each condition, were excluded from the calculations (less than 5\%). Mean RTs and error rates were calculated in each of the conditions across participants and are presented in Table 2.

The statistical reliability of the observed differences was established across subjects and across stimuli by two-way within-subjects analysis of variance (ANOVA). The factors were priming language (SA, LA, and Hebrew) and repeatedness (repeated/translated, unrepeated). These analyses showed that the RTs to SA targets following SA primes $(890 \mathrm{~ms})$ were faster than the RTs to SA targets following LA primes (938 $\mathrm{ms}$ ) and the RTs to SA targets following Hebrew primes (1034 ms) [F1(1.29) = 99.9, $\mathrm{MSe}=1742, \mathrm{p}<0.001 ; \mathrm{F} 2(1,180)=9.45, \mathrm{MSe}=1742$, $\mathrm{p}<0.001]$. The results also showed a significant main effect of repeatedness $[\mathrm{F} 1(1,290)=99.7, \mathrm{MSe}=5063, \mathrm{p}<0.001$; $\mathrm{F} 2(2,180)=37.0, \mathrm{MSe}=8343, \mathrm{p}<0.001]$. Post-hoc comparisons of the repeatedness effect revealed that RTs to targets succeeding unrelated primes were the slowest (1063 ms) and were significantly slower than those appearing after noncognate translations $(946 \mathrm{~ms})[\mathrm{F} 1(1,29)=68.0$, $\mathrm{MSe}=22842, \mathrm{p}<0.001]$. A significant interaction emerged when repeatedness interacted with the priming language, showing that the repeatedness effect on SA targets was larger if priming was induced by identical words in SA (185 ms) than by translation equivalents in LA ( $84 \mathrm{~ms})$ and in Hebrew $(83 \mathrm{~ms})[\mathrm{F}(2,58)=4.7, \mathrm{MSe}=1979, \mathrm{p}<0.025]$.

Concerning the percentage of errors, less errors were made to primed than to unprimed word targets $[\mathrm{F} 1(2,58)=86.8$, $\mathrm{MSe}=21.5, \mathrm{p}<0.001]$. The priming language, however, had no influence on the percentage of errors made to word targets $[\mathrm{F} 1(1,29)=1.58, \mathrm{MSe}=22.14, \mathrm{p}=0.218 ; \mathrm{F} 2(1,179)$ $<1.00]$. Post-hoc univariate analysis revealed that priming reduced the percentage of errors more effectively when the translation was from LA to SA (3.85\%) and from Hebrew to SA $(5.25 \%)$ than from SA to SA $(8.1 \%)$. This pattern is compatible with that found in the analysis of RTs and suggests that subjects may use a strategic means of identifying a different language from SA.

\section{Experiment 2 \\ Method}

\section{Participants}

The participants were 60 students in the 11 th and 12 th grades at Druze schools. All were native (spoken) Arabic speakers who had started to learn LA at school in the first grade and Hebrew in the second grade. All participants were right-handed and neurologically normal and without any known learning disabilities. All participants had passed the

Table 2 Reaction times in milliseconds (SEM*) and percentage of errors in lexical decisions for word targets in spoken Arabic (SA), primed by SA and noncognate translation equivalents in literary Arabic and Hebrew at lag 0

\begin{tabular}{llll}
\hline Repeated condition & \multicolumn{2}{l}{ Language of the prime } & Hebrew \\
\cline { 2 - 4 } & Spoken Arabic & Literary Arabic & $1010(17) 2.9 \%$ \\
\hline Repeated target & $890(16) 4.8 \%$ & $938(16) 1.0 \%$ & $1093(19) 7.6 \%$ \\
Unrepeated target & $1074(24) 11.4 \%$ & $1022(23) 6.7 \%$ & $\mathbf{8 3} \mathbf{~ m s}$ \\
Priming effect & $185 \mathbf{~ m s}$ & $\mathbf{8 4}$ & $\mathbf{m s}$ \\
\hline
\end{tabular}

Abbreviation: SEM, standard error of the mean. 
high school entrance examination in Hebrew. Given their similar language background, a general L2 language history questionnaire was not collected. ${ }^{27}$

\section{Stimuli and design}

The stimuli were 192 targets (96 words and 96 pseudowords) and 192 primes (96 words and 96 pseudowords) (see list of words in Appendix). All translation equivalent repetition pairs were noncognates and limited to clearly dominant translations. The list was chosen by 30 judges from the same student population who were not participating in the experiment itself, and translations that were not agreed upon were excluded. Among the targets, 48 words and 48 pseudowords were repeated (within or across languages, with 16 targets in each group), while the remaining 48 words and 48 pseudowords were paired with different words or pseudowords. As in Experiment 1, the stimuli were recorded in a male voice in the local SA dialect, and were presented to the participants orally through earphones by a computer.

\section{Procedure}

At the beginning of the experimental session, instructions were given in SA that the participants should indicate, by pressing one of two buttons, whether each phonological string presented was a word or a pseudoword, regardless of the language of presentation. The dominant hand was used for the affirmative (detection of a word) and the other hand for the negative (detection of a pseudoword). Accuracy and speed of the lexical decision were equally stressed. The stimuli were presented at a steady rate, and the duration of the experimental session was 20 minutes. The experimental session was preceded by a training session in which 16 words and 16 pseudowords were presented.

Since half of the stimuli were words and the other half pseudowords, and since both words and pseudowords were similarly structured and randomly presented, the participants were not able to predict the lexical status of any stimulus based on the preceding stimulus. As far as the participants were concerned, the stimuli on the list were not related in any way and the paired structure existed in the eyes of the experimenter alone. All stimuli were presented sequentially at fixed time intervals, and the subjects were instructed to make a word/nonword decision for each stimulus. The stimulus onset asynchrony (SOA) was $2000 \mathrm{~ms}$, and the order of presentation was pseudorandomized (keeping pairing intact) for each subject.

In the literature, the effect that "people are normally faster when they repeat the same task than when they switch tasks" is more often referred to as "mixing costs." Meuter and Allport ${ }^{28}$ asked bilingual subjects to unpredictably name numerals in either L1 or L2. They found that RTs were much faster in nonswitching trials than in switching trials. Most unexpectedly, switching costs were larger when switching occurred between the dominant L1 and the weaker L2 than vice versa. In this study, a pseudorandom order of presentation was conducted and the frequency of language switches was controlled. As such, the probability of the target in SA (whether repeated or not) following words or pseudowords was similar in each of the languages. This procedure assures that the results are not confounded with language-switching costs. ${ }^{28}$

\section{Results}

Reaction times deviating by more than two standard deviations from the participant's average were less than 5\% and were not included in the analysis. The repetition effect was analyzed within subjects (F1) and between stimulus type (F2). For both RT and accuracy, large repetition effects were found when both the prime and the target were in SA, while priming by translation equivalents was extremely weak regardless of the language in which the first word was presented (see Tables 2 and 3 ).

A 3 (prime language) $\times 2$ (repetition status) repeated measures ANOVA of the RTs showed that the repetition effect was significant $[\mathrm{F} 1(1,59)=62.41, \mathrm{MSe}=3407, \mathrm{p}<0.001$; $\mathrm{F} 2(1,95)=20.9, \mathrm{MSe}=11770, \mathrm{p}<0.001]$, as was the effect

Table 3 Reaction times in milliseconds (SEM) and percentage of errors in lexical decisions for targets in spoken Arabic (SA), primed by translation equivalents in SA, literary Arabic, and Hebrew at lags 8-12

\begin{tabular}{llll}
\hline Repeated condition & \multicolumn{3}{l}{ Language of the prime } \\
\cline { 2 - 4 } & Spoken Arabic & Literary Arabic & Hebrew \\
\hline Repeated target & $930(8.9) 6.3 \%$ & $1040(17.2) 11.0 \%$ & $1034(14.3) 9.7 \%$ \\
Unrepeated target & $1055(14.7) 10.2 \%$ & $1045(14.6) 10.8 \%$ & $1050(15.1) 11.9 \%$ \\
Priming effect & $125 \mathbf{~ m s}$ & $\mathbf{5 ~ m s}$ & $16 \mathbf{~ m s}$ \\
\hline
\end{tabular}

Abbreviation: SEM, standard error of the mean. 
of priming-language $[\mathrm{F} 1(2,118)=13.81, \mathrm{MSe}=7187.21$, $\mathrm{p}<0.001 ; \mathrm{F} 2(2,190)=16.6, \mathrm{MSe}=7087, \mathrm{p}<0.001]$. More importantly, a significant interaction was found between the repetition effect and the priming-language $(\mathrm{F} 1(2,118)=34.3$, $\mathrm{MSe}=3816, \mathrm{p}<0.001 ; \mathrm{F} 2(2,190)=56.2, \mathrm{MSe}=5394$, $\mathrm{p}<0.001]$. Post-hoc analysis revealed that while the intralingual SA repetition induced a significant priming-language effect $[\mathrm{F} 1(1.59)=70.2, \mathrm{MSe}=6653, \mathrm{p}<0.001$; $\mathrm{F} 2(1.95=143.9, \mathrm{MSe}=5790, \mathrm{p}<0.001]$, there was no significant cross-lingual repetition effect, regardless of whether the first presentation was in LA $[\mathrm{F} 1(1.59)<1.00$; $\mathrm{F} 2(1.95)=2.0, \mathrm{MSe}=7353, \mathrm{p}=16]$ or in Hebrew $[\mathrm{F} 1(1.59)=3.1, \mathrm{MSe}=2600, \mathrm{p}=0.09 ; \mathrm{F} 2(1.95)<1.00]$. The priming-language factor had no influence on the RTs to unrepeated target words $[\mathrm{F} 1(2,118)<1.00$; $\mathrm{F} 2(2,190)<1.00]$.

Analysis of the error rates revealed a similar pattern. The main effect of repetition was significant $[\mathrm{F} 1(1,59)=16.3$, $\mathrm{MSe}=30, \mathrm{p}<0.001]$, but qualified by a significant repetition $\times$ priming-language interaction $[\mathrm{F} 1(2,118)=7.37$, $\mathrm{MSe}=62, \mathrm{p}<0.001]$. As before, post-hoc analysis showed that while intra-lingual repetition significantly enhanced the accuracy $(\mathrm{F} 1(1,59)=8.5, \mathrm{MSe}=42, \mathrm{p}<0.001)$, cross-lingual repetition did not significantly reduce the error rates, either when the first presentation was in LA $(\mathrm{F} 1(1,59)<1.00)$ or in Hebrew $(\mathrm{F} 1(1,59)=3.7, \mathrm{MSe}=62.4$, $\mathrm{p}=0.114)$. No significant differences were found between the errors elicited by unrepeated targets in the three languages $[\mathrm{F} 1(2,118)=2.35, \mathrm{MSe}=89.5, \mathrm{p}=0.10]$.

The results suggest that identity repetition significantly reduced reaction time and increased the accuracy of lexical decisions for repeated SA targets. In contrast, previous presentation of either LA or Hebrew translation equivalents did not affect the lexical decisions for SA targets. However, because these effects might have been induced by semantic and phonological cues, rather than lexical factors, it was important to determine first that the lexical repetition effects between translation equivalents in LA and SA are typical to those found across L2 and L1. This point was indeed determined in Experiment 2.

\section{Discussion}

In a previous study, ${ }^{7}$ the question of language organization in the context of the semantic level was directly addressed by comparing the semantic priming effects within SA (L1) with the effects found across languages, with LA or Hebrew as the other language (L2). The pattern of semantic priming effects suggests that, in regard to their connections with the semantic network, the status of LA is similar to that of Hebrew. In this study, the psycholinguistic reality that influences bilingual performance was examined by directly focusing on lexical organization.

Two experiments were conducted. Experiment 1 examined the lexical repetition effects at short lags (lag 0 ) between translation equivalents in SA and LA and in SA and Hebrew. It was important to examine this condition in order to determine that these effects were not induced by semantic factors, rather than lexical factors, as indeed determined in Experiment 2. In the second experiment, repetition factors were manipulated by comparing the effects within SA, across SA and LA, and across SA and Hebrew by inserting 8-12 unrelated words between the first and second appearance of the word (intra-lingual repetition) or between the word and its translation equivalent (cross-lingual repetition).

The results revealed that presenting words in SA as primes led to faster and more accurate performance of lexical decisions for targets in SA and that this facilitation was greater than when words in SA were primed by translation equivalents in Hebrew or in LA. However, whereas these pairs maintained a similar pattern of priming at different lags, there was a decrease in priming at lag 8-12 relative to immediate repetition (lag 0 ). The repetition effects between translation equivalents at lag 0 and the absence of such effects at lag 8-12 suggest that form repetition might have partly accounted for the overall larger repetition effects for words at lag 0 than at longer lag times.

However, this repetition effect for noncognate translation equivalents demonstrates that neither form nor any other type of shallow analysis can be the single explanatory factor. This interpretation is consistent with studies in the visual modality, in which the translation occurred between languages with different orthographies, such as Korean and English ${ }^{29}$ or Chinese and English. ${ }^{30}$ Furthermore, although semantic factors might explain the repetition effects across noncognate translation equivalents at lag 0 , the fact still remains that translation equivalents are also linked at the lexical level.

The absence of cross-lingual repetition priming at long lags was in sharp contrast with the significant intra-lingual repetition effect within SA. These findings suggest that the links between LA and SA words are similar to those between Hebrew and SA words, both reflecting the typical organization of L2 in a separate lexicon. ${ }^{31,32}$ This raises the question as to what extent the pattern of standard repetition priming results reflects the lexical organization of first and second languages. An obvious difference between cross-lingual and 
intra-lingual repetition is that the latter entails repetition of the perceptual record as well as reactivation of the identical concept, whereas only the concept is repeated in noncognate translation equivalents.

The absence of long-lasting priming between phonologically dissimilar LA and SA translation equivalents, as well as between synonyms, ${ }^{33}$ suggests that the consequences of repeated access to identical or partly overlapping semantic representations (per se) on performance are short-lived. Namely, the failure to find such priming effects is compatible with an explanation of synonyms in a single lexicon. As Roediger and Blaxton ${ }^{33}$ argued, the similar outcome can be predicted because the two items are two separate entries in the lexicon and do not share phonology and form.

The present results do not support the existence of a classic shared lexicon for both the SA and LA forms of Arabic. Thus, it has yet to be determined as to which of the two bilingual representation models (single lexicon and separated lexicons) will prevail. On the basis of the above analysis, however, it may be suggested that three linguistic and nonlinguistic factors determine the magnitude of the priming effect across the two priming languages at different lags.

First, the active lexical links found between translation equivalents exist in parallel to conceptual semantic overlap and are sensitive to the phonemic structure of the words. This semantic overlap is largest at lag 0 and reduced at lag 8-12, meaning that when the semantic connections were neutralized by inserting $8-12$ fillers between the prime and the target, there was no significant cross-lingual repetition effect. The second factor is related to episodically established lexical associations between translation equivalents. Apparently, the influence of this factor is short-lived and not effective for lags of 8-12 items. Hence, the reaction time to target words in SA was not influenced by the previous appearance of its translation equivalent in LA or Hebrew. However, the long-lasting repetition effects within SA reflect the (implicit) reactivation of an episodic trace installed by the prime. One could claim that the LA words take more to process, and hence produce less priming. The effective information contained in this trace is most likely lexical. ${ }^{22}$ Support for this suggestion comes from, for example, studies showing that nonword repetition effects are limited to very short $\operatorname{lags}^{25,34}$ and that form (orthographic) repetition is effective only if the prime is masked, ${ }^{35}$ but is significantly reduced if the repetition is delayed by even one intervening item. ${ }^{36}$ Nevertheless, the absence of active lexical links between translation equivalents is not evidence that such links do not exist or cannot be reactivated when the task or the linguistic environment deems it necessary. However, this do not contradict the notion of being the two languages separated because different languages similar in origin that are represented in separate lexicons, by definition sound untypical and listeners have hard times determining which variety they belong to.

Finally, the third factor supports the notion of a lexical familiarity in basic native Arabic sounds, forms, structures, and syllabic and prosodic features between LA and SA. If not identical, they may at least show important and striking similarities. De Groot $^{37}$ accounted for the morphophonemic similarity effect by assuming that, having a common etymology, cognate translation equivalents share more meaning features than do noncognate translation equivalents, thus making priming between cognate translations more effective than between noncognate translations. In essence, according to this view, repetition priming between translation equivalents, like semantic priming, originates from the activation of common semantic features in the conceptual system. Furthermore, the larger priming effect found at lag 0 when the primes were in Hebrew may also reflect a greater sensitivity to morpho-phonological form similarity, that is, a more analytic/segmental perceptual strategy for second languages than for the mother tongue. Similar results were reported in a masked-priming study suggesting that sharing a common root affects the processing of the target during bottom-up processing. ${ }^{38}$

Assuming that a major source of long-lasting repetition priming effect is the reactivation of a lexically based episodic trace, the absence of such priming across noncognate translation equivalents implies that the recognition of a word in one language does not entail the lexical activation of its translation equivalent. Furthermore, because the cross-lingual priming in the present experiment was from L2 to L1 (ie, the primes were in L2 and the targets in L1), the absence of long-lasting priming effects demonstrates that in bilinguals, the identification of words in L2 is not mediated by their translation equivalents in L1. ${ }^{12}$ An explanation for this result is probably related to the consequence of episodic lexical associations based on mundane use. Specifically, it may be suggested that nonlinguistic factors qualified the influence of the linguistic factors in determining the magnitude of these effects. Among these factors are episodic associations, which are equally strong between translation equivalents in two languages that are interactively and concomitantly used on an everyday basis (LA and Hebrew).

Indeed, the influence of phonemic similarity (comparing cognate and noncognate pseudowords) on priming between 
translation equivalents has been well established in cross-lingual semantic priming and repetition priming. ${ }^{39}$ This hypothesis was recently examined, ${ }^{40}$ and both studies suggest that the cognitive level at which these links are effective is still debatable. The second-language argument for LA is also seriously weakened by the fact that only noncognate words were used as primes in the study. The two studies that compared cognate and noncognate translation equivalents concluded that priming between cognate translations is more effective than between noncognate translations. The studies using cognate rather than noncognate LA words as primes might very well support a single lexicon model or, more likely, an interactive activation model.

Since long-lasting repetition effects between translation equivalents would, "by necessity," indicate the existence of lexical links or reactivation of the same concept, and since SA-LA pairs in Arabic are of both types, the issue can not be resolved by claiming that some words exist in a shared lexicon and others in separated lexicons. It seems that only a distributed interactive activation model could handle both cognate and noncognate effects and that the "bilingualism" argument would dissolve at that point (see, for example, Hinton and colleagues ${ }^{41}$ and the BIA++ model of Dijkstra and van Jeuven). ${ }^{42}$ With respect to semantics and phonology, the BIA++ model of Dijkstra and van Jeuven $^{42}$ proposes an integration of codes at sub-lexical levels (eg, in terms of the letters), and not only at the lexical level. Comparing these and other models (eg, the distributed conceptual representations model of McClelland and colleagues $)^{43}$ by testing them empirically may be undertaken in future research. Such studies in Arabic will clarify the contributions of phonological, orthographic, and semantic codes to the bilingual word recognition process. Using stimuli in the visual modality, these considerations suggest that form-identical cognates and inter-lingual homographs have their own whole-word orthographic representation for each language. In other words, they are represented in the same way as items that are similar, but not identical, in form across languages. In addition, each representation is characterized by its word frequency in the language to which it belongs.

In conclusion, the overall results of the two experiments lead to the conclusion that not only are native Arab speakers less skilled in LA and Hebrew than in SA, but that based on the contributions to priming, there are sufficient data to claim that learning LA is, in some respects, more like learning a second language than like learning the formal register of one's native language. In that regard, from a psycholinguistic perspective, the literate Arabic speaker may be considered de facto as bilingual.

\section{Disclosure}

The author reports no conflicts of interest in this work.

\section{References}

1. Kroll JF, de Groot AMB. Lexical and conceptual memory in the bilingual: Mapping form to meaning in two languages. In: de Groot AMB, Kroll JF, editors. Tutorials In Bilingualism: Psycholinguistic perspectives. Mahwah, NJ: Lawrence Erlbaum; 1997. pp. 201-224.

2. Grainger J, Frenck-Mestre C. Masked priming by translation equivalents in proficient bilinguals. Lang Cogn Process. 1998;13:623-901.

3. Maamouri M. Language Education and Human Development: Arabic diglossia and its impact on the quality of education in the Arab region. The Mediterranean Development Forum. Washington, DC: The World Bank; 1998.

4. Abu-Rabia S. Effects of exposure to literary Arabic on reading comprehension in a diglossic situation. Reading and Writing. 2000;13:147-157.

5. Saiegh-Haddad E. Linguistic distance and initial reading acquisition: The case of Arabic diglossia. Appl Psycholinguist. 2003;24:431-451.

6. Eviatar Z, Ibrahim R. Bilingual is as bilingual does: Metalinguistic abilities of Arabic-speaking children. Appl Psycholinguist. 2001; 21(4):451-471.

7. Ibrahim R, Aharon-Peretz J. Is literary Arabic a second language for native Arab speakers? Evidence from a semantic priming study. J Psycholinguist Res. 2005;34(1):51-70.

8. Ibrahim R, Eviatar Z, Aharon Peretz J. Metalinguistic awareness and reading performance: A cross language comparison. J Psycholinguist Res. 2007;36(4):297-317.

9. Bialystok E. Language Processing in Bilingual Children. Cambridge, UK: Cambridge University Press; 1991.

10. Wranger DA, Spratt JE, Ezzaki A. Does learning to read in a second language always put the child at a disadvantage? Some counter evidence from Morocco. Appl Psycholinguist. 1989;10:31-48.

11. Abunuwara E. The structure of the trilingual lexicon. Eur J Cogn Psychol. 1992;4(4):311-322.

12. Kroll JF, Stewart E. Category interference in translation and picture naming: Evidence for asymmetric connection between bilingual memory representations. J Mem Lang. 1994;33:149-174.

13. Altarriba J. Constraints of Interlingual Facilitation Effects in Priming in Spanish-English Bilinguals. Unpublished dissertation. Nashville, TN: Vanderbilt University; 1990.

14. Keatly C, Spinks J, de Gelder B. Asymmetrical semantic facilitation between language. Mem Cognit. 1994;22:70-84.

15. Kirsner K. Lexical representation: Is a bilingual account necessary? In: Vaid J, editor. Language Processing in Bilinguals: Psycholinguistic and neuropsychological perspectives. Hillsdale, NJ: Lawrence Erlbaum; 1986.

16. Sholl A, Sankaranarayanan A, Kroll JF. Transfer between picture naming and translation: A test of asymmetries in bilingual memory. Psychol Sci. 1995;6:45-49.

17. Tzelgov J, Henik A, Leiser D. Controlling Stroop interference: Evidence from bilingual task. J Exp Psychol Learn Mem Cogn. 1990;16: 760-771.

18. Saiegh-Haddad E. The impact of phonemic and lexical distance on the phonological analysis of word and pseudowords in a diglossic context. Appl Psycholinguist. 2004;25:495-512.

19. Abu-Rabia S. Druze minority students learning Hebrew in Israel: The relationship of attitudes, cultural background, and interestingness of material with reading comprehension in a second language. The Journal of Multilingual and Multicultural Development. 1996;17(6):415-426. 
20. Seginer R, Halabi-Kheir H. Adolescent passage to adulthood: Future orientation in the context of culture, age, and gender. Int J Intercult Relat. 1998;22:309-328.

21. Keatley C, DeGelder B. The bilingual primed lexical decision task: cross language priming disappears with speeded responses. Eur J Cogn Psychol. 1992;4(4):273-292.

22. Monsell S. Repetition and the lexicon. In: Ellis AW, editor. Progress in the Psychology of Language. Vol. 2. London, UK: Lawrence Erlbaum Associates Ltd; 1985. pp. 147-197.

23. Rueckl JG, Mikolinski M, Raveh M, Miner C, Mars F. Morphological priming, fragment completion, and connectionist networks. J Mem Lang. 1997;36:382-345.

24. Ratcliff R, Hockley W, McKoon G. Components of activation: Repetition and priming effects in lexical decision and recognition. J Exp Psychol Gen. 1985;114:50-77.

25. Bentin S, Moscovitch M. The time course of repetition effects for words and unfamiliar faces. J Exp Psychol Gen. 1988;117:148-160.

26. Bentin S, Feldman LB. The contribution of morphological and semantic relatedness to repetition priming at short and long lags: Evidence from Hebrew. Q J Exp Psychol A. 1990;42(4):693-711.

27. Li P, Sepanski S, Zhao X. Language history questionnaires: A web-based interface for bilingual research. Behav Res Methods. 2006;38:202-210.

28. Meuter RFI, Allport A. Bilingual language switching in naming: Asymmetrical costs of language selection. J Mem Lang. 1999; 40:25-40.

29. Jin YS, Fischler I. Effects of concreteness on cross-language priming of lexical decision. Atlanta, GA: Presented at the Southeastern Psychological Association Meeting; 1987.

30. Chen $\mathrm{HC}, \mathrm{Ng}$ ML. Semantic facilitation and translation priming effects in Chinese-English bilinguals. Mem Cognit. 1989;17:454-462.

31. Kirsner K, Brown HL, Abrol S, Chadha NK, Sharma NK. Bilingualism and lexical representation. Q J Exp Psychol. 1980;32:585-594.

32. Gerard LD, Scarborough DL. Language specific lexical access of homographs by bilinguals. J Exp Psychol Learn Mem Cognit. 1989;15: 305-315.
33. Roediger HL, Blaxton TA. Effects of varying modality, surface features and retention interval on priming in word fragment completion. $\mathrm{Mem}$ Cognit. 1987;15:379-388.

34. Kirsner K, Dunn J, Standen P. Record-based word recognition. In: Coltheart M, editor. Attention and Performance XII: The psychology of reading. Hillsdale, NJ: Lawrence Erlbaum; 1987. pp. 147-167.

35. Humphreys GW, Evett LJ, Quinlan PT, Besner D. Orthographic priming: Qualitative differences between priming from identical and unidentified primes. In: Coltheart M, editor. Attention and Performance XII: The psychology of reading. Hillsdale, NJ: Lawrence Erlbaum; 1987. pp. 105-146.

36. Forster KI. Form-priming with masked primes: The best match hypothesis. In: Coltheart M, editor. Attention and Performance XII: The psychology of reading. Hillsdale, NJ: Lawrence Erlbaum; 1987. pp. 127-146.

37. de Groot AMB. Determinants of bilingual lexicosemantic organization. Comput Assist Lang Learn. 1995;8:151-180.

38. Frost R, Katz L, Bentin S. Strategies for visual word recognition and orthographical depth: a multilingual comparison. J Exp Psychol Hum Percept Perform. 1987;13:104-114.

39. de Groot MBA, Nas LJG. Lexical representation of cognates and noncognates in compound bilinguals. J Mem Lang. 1991;30:90-123.

40. Ibrahim R. Morpho-phonemic similarity within and between languages: A factor to be considered in processing Arabic and Hebrew. Reading and Writing. 2006;19(6):563-586.

41. Hinton GE, McClelland JL, Rumelhart DE. Distributed representations. In: Rumelhart DE, McClelland JL; and the PDP Research Group. Parallel distributed processing: Explorations in the microstructure of cognition, Vol. 1: Foundations. Cambridge, MA: MIT Press; 1986.

42. Dijkstra T, van Jeuven WJB. The BIA model and bilingual word recognition. In: Grainger J, Jacobs AM, editors. Localist Connectionist Approaches to Human Cognition. Mahwah, NJ: Lawrence Erlbaum Associates; 1998. pp. 189-225.

43. McClelland JL, Rumelhart DE, Hinton GE. The appeal of parallel distributed processing. In: Rumelhart DE, McClelland JL, editors Parallel Distributed Processing. Cambridge, MA: MIT Press; 1986. 
Appendix I Spoken Arabic targets and their rated frequencies and Literary Arabic and Hebrew noncognate primes and their English translations

\begin{tabular}{|c|c|c|c|c|c|c|c|}
\hline $\begin{array}{l}\text { Targets: } \\
\text { Spoken } \\
\text { Arabic }\end{array}$ & $\begin{array}{l}\text { Primes: } \\
\text { Literary } \\
\text { Arabic }\end{array}$ & Freq & English & $\begin{array}{l}\text { Targets: } \\
\text { Spoken } \\
\text { Arabic }\end{array}$ & $\begin{array}{l}\text { Primes: } \\
\text { Hebrew }\end{array}$ & Freq & English \\
\hline ل بـر اد & ثلاجة & 3.8 & Refrigerator & برودة & רובה & 3.9 & Rifle \\
\hline آويس & جيد & 3.0 & Good & برواز & מסגרת & 4.3 & Frame \\
\hline تبرين & قطار & 5.0 & Train & دفاي & תנור & 4.3 & Oven \\
\hline داب & حمار & 3.5 & Donkey & بسكليت & אופניים & 4.3 & Bicycle \\
\hline حيّة & ا فعى & 4.2 & Snake & طاقية & כובע & 4.2 & Hat \\
\hline قرقيعة. & سلحفاة & 3.4 & Turtle & واوي & שועל & 4.4 & Fox \\
\hline فر مشيّة & صديدليّة & 4.8 & Pharmacy & شفاطة & משאבה & 4.4 & Pump \\
\hline نتفة & قليل . & 4.5 & Little & بريك & בלם & 3.8 & Brake \\
\hline برندة & شرفة & 4.6 & Balcony & سترجي & העיז & 3.0 & Dare \\
\hline دغري & ستقيم & 4.3 & Straight & آرستا & חומר & 3.0 & Material \\
\hline بدّي & اريد & 5.2 & Want & هم & התנפל & 3.8 & Attack \\
\hline بلاش & مجانا & 4.4 & Free & شلعة & עדר & 3.9 & Herd \\
\hline صحتين & منيئا & 3.1 & Appetite & ولع & הדליק & 4.0 & Burn \\
\hline أوتيل & فندق & 4.8 & Hotel & مواي & מאוורר & 4.0 & Fun \\
\hline وقعة & وجبة & 4.7 & Meal & تنكة & פחית & 3.9 & Can \\
\hline فلاس & ملل مل & 4.4 & Bored & مصرين & מעיים & 3.6 & Guts \\
\hline بلَ & بدأ & 4.8 & Begin & محرمة & מטפחת & 4.3 & Sheet \\
\hline مذول & مؤلاء & 4.7 & Those & علبة & קופסה & 4.1 & Box \\
\hline ططلة & مربَى & 4.1 & Maiden & سايط & אדיש & 3.4 & Apathetic \\
\hline بودرة & مسحوق & 3.2 & Powder & قحة & שיעול & 4.5 & Cough \\
\hline صبرة & حظيرة & 3.8 & Fold & فيق & העיר & 4.6 & Wake \\
\hline برداي & ستار & 3.7 & Curtain & طمرجي & אח & 4.5 & Paramedic \\
\hline آبَو ت & معطف & 4.0 & Jacket & اوضة & חדר & 4.2 & Room \\
\hline زلمة & رجل & 3.8 & Man & حروش & מלון & 5.0 & Melon \\
\hline شحّاط & آبريت & 4.7 & Matches & استحى & התבייש & 3.3 & Shameful \\
\hline آيف & فرح & 4.6 & Glad & بنادم & אדם & 3.3 & Person \\
\hline
\end{tabular}


Appendix I (Continued)

\begin{tabular}{|c|c|c|c|c|c|c|c|}
\hline Targets: & Primes: & Freq & English & Targets: & Primes: & Freq & English \\
\hline Spoken & Literary & & & Spoken & Hebrew & & \\
\hline Arabic & Arabic & & & Arabic & & & \\
\hline لبطة & رآلة & 3.3 & Kick & برة & בחוץ & 4.6 & Outside \\
\hline بشكير & منشفة & 5.3 & Towel & نبريج & צינור & 3.0 & Pipe \\
\hline شوفير & سائق & 4.7 & Driver & آند رة & נעליים & 3.7 & Shoes \\
\hline أجر & جنازة & 3.4 & Funeral & بكس & אגרוף & 3.3 & Fist \\
\hline بكرة & غدا & 4.3 & Tomorrow & ناصح & שמן & 4.4 & Fat \\
\hline آلسات & جو ارب & 4.9 & Socks & متهنة & משוגע & 3.5 & Crazy \\
\hline
\end{tabular}

Psychology Research and Behavior Management

\section{Publish your work in this journal}

Psychology Research and Behavior Management is an international, peerreviewed, open access journal focusing on the science of psychology and its application in behavior management to develop improved outcomes in the clinical, educational, sports and business arenas. Specific topics covered include: Neuroscience, memory \& decision making; Behavior modification \& management; Clinical applications; Business \& sports performance management; Social and developmental studies; Animal studies. The manuscript management system is completely online and includes a quick and fair peer-review system. Visit http://www.dovepress. com/testimonials.php to read real quotes from published authors.

Submit your manuscript here: http://www.dovepress.com/psychology-research-and-behavior-management-journal 